\title{
0863. Lithium pharmacokinetics in the rat according to the three different modalities of human poisoning
}

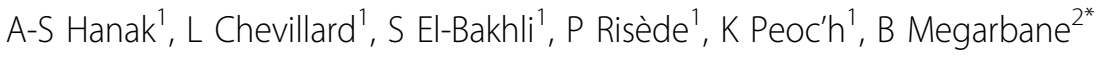 \\ From ESICM LIVES 2014 \\ Barcelona, Spain. 27 September - 1 October 2014
}

\section{Introduction}

Lithium-related neurological toxicity may be severe resulting in seizures, myoclonic encephalopathy, and coma. Three different poisoning presentations exist in humans, including acute poisoning in non-previously treated patients $(\mathrm{A})$, acute-on-chronic poisoning $(\mathrm{A} / \mathrm{C})$, and therapeutic overdose $(\mathrm{T})$. The exact reasons why severity and features are different between these three presentations are unknown, although differences in brain lithium distribution have been suggested.

\section{Objectives}

Our objective was to study lithium pharmacokinetics in blood and brain in rat models corresponding to each human presentation.

\section{Methods}

Development of three models of lithium intoxication in Sprague Dawley rats: A (one intraperitoneal injection of $185 \mathrm{mg} / \mathrm{kg} \mathrm{Li}{ }_{2} \mathrm{CO}_{3}$ ); $\mathrm{A} / \mathrm{C}$ (800 or $1600 \mathrm{mg} / \mathrm{L} \mathrm{Li}_{2} \mathrm{CO}_{3}$ in the drinking water followed by one intraperitoneal injection of $185 \mathrm{mg} / \mathrm{kg} \mathrm{Li}_{2} \mathrm{CO}_{3}$ at day 28$) ; \mathrm{T}\left(\mathrm{K}_{2} \mathrm{Cr}_{2} \mathrm{O}_{7}\right.$-induced acute renal failure on day 1 followed by intraperitoneal injections of $74 \mathrm{mg} / \mathrm{kg} /$ day $\mathrm{Li}_{2} \mathrm{CO}_{3}$ during 5 days); determination of plasma, erythrocyte, cerebrospinal fluid, and brain lithium concentrations using inductively coupled plasma atomic emission spectroscopy (quantification threshold: $0.6 \mathrm{nmol} / \mathrm{L}$ ); modeling and determination of pharmacokinetics parameters; comparisons with nonparametric tests.

\section{Results}

Lithium followed a tricompartmental pharmacokinetics with a shortened plasma half-life in case of previous chronic exposure (1.73 vs. $3.85 \mathrm{~h}$ ). The peak lithium concentration was measured at $6 \mathrm{~h}$ in erythrocytes, $2 \mathrm{~h}$ in cerebrospinal fluid, and $24 \mathrm{~h}$ in the brain in both $\mathrm{A}$ and $\mathrm{A} / \mathrm{C}$ models; however, the elimination constants k21 (erythrocytes-to-plasma) and k31 (brain-to-plasma) were lower in the $\mathrm{A} / \mathrm{C}$ model ( 0.36 versus 0.56 and 2.1 versus 9.2 , respectively), suggesting lithium accumulation. The brain distribution was not homogeneous, with rapid entrance (as soon as $15 \mathrm{~min}$ ), peak at $24 \mathrm{~h}$, and delayed elimination $(>78 \mathrm{~h})$. Lithium accumulation into the brain was more marked in the presence of previous chronic exposure (brain-to-plasma ratio at 54h: 131.27 vs. 6.42; $\mathrm{p}<0.0001$ ). Similarly, alteration in renal elimination resulted in increased brain distribution (brain-to-plasma ratio: 10.98 vs. 6.88).

\section{Conclusions}

Our experimental models suggest that the three different presentations of lithium poisonings in humans differ due to lithium blood pharmacokinetics and brain distribution. However, the hypothesis of an additional variability related to different interactions of lithium with neurological targets in each presentation could not be ruled out.

\footnotetext{
Authors' details

${ }^{1}$ INSERM U 1144, Paris-Descartes University, Paris, France. ${ }^{2}$ Lariboisière Hospital, INSERM U 1144, Paris-Diderot University, Paris, France.
} 


\section{Submit your manuscript to a SpringerOpen ${ }^{\circ}$ journal and benefit from:}

- Convenient online submission

- Rigorous peer review

- Immediate publication on acceptance

- Open access: articles freely available online

- High visibility within the field

- Retaining the copyright to your article

Submit your next manuscript at $\gg$ springeropen.com 